\title{
THE RENAL EXCRETION OF HYDROGEN IONS IN INFANTS AND CHILDREN
}

\author{
BY \\ ALEXANDER PEONIDES, BARNETT LEVIN, and WINIFRED F. YOUNG \\ From the Queen Elizabeth Hospital for Children, London
}

(RECEIVED FOR PUbliCATION AUGUST 24, 1964)

The ability of the kidneys to excrete an acid urine is often assessed by correlating plasma carbon dioxide and urine $p \mathrm{H}$. A low plasma $\mathrm{CO}_{2}$ should be accompanied by a low urine $p \mathrm{H}$, provided that respiratory function is normal. Buchanan and Komrower (1958) consider that the renal excretion of hydrogen ions is normal in children if urine $p \mathrm{H}$ falls below $5 \cdot 0$, after a single dose of $0 \cdot 1 \mathrm{~g} . / \mathrm{kg}$. of ammonium chloride has been given to produce metabolic acidosis. Under similar conditions, urine $p \mathrm{H}$ falls to below $5 \cdot 2$ in normal adults (Wrong and Davies, 1959). However, Elkinton, Huth, Webster, and McCance (1960) found that urine $p \mathrm{H}$ was not sufficient to differentiate latent cases of renal tubular acidosis in adults after prolonged administration of $\mathrm{NH}_{4} \mathrm{Cl}$. These authors suggested a quantitative assessment of the renal response to an ammonium chloride load by the 'hydrogen ion clearance index' calculated as the product of the total $\mathrm{H}^{+}$excreted in the urine $(\mathrm{mEq} / \mathrm{min} . / 1 \cdot 73 \mathrm{sq} . \mathrm{m}$.) and the plasma $\mathrm{CO}_{2}$ content $(\mathrm{mEq} / \mathrm{l}$.) in subjects after a continuous $\mathrm{NH}_{4} \mathrm{Cl}$ administration for 3-5 days. Abnormally low values of the index were considered to indicate renal acidosis. This index has not only proved a sensitive one in cases with latent renal tubular acidosis, but also useful in revealing the latent renal defect in otherwise normal relatives of patients with renal tubular acidosis, thus contributing to our knowledge of the genetics of the disease (Huth, Webster, and Elkinton, 1960).

In the present study the renal $\mathrm{H}^{+}$excretion on normal diet, as well as after the addition of $\mathrm{NH}_{4} \mathrm{Cl}$ for several days, has been investigated in order to determine values for the hydrogen ion clearance index in normal infants and children. Results from similar investigations in children with renal tubular acidosis and their relatives will be reported later.

Subjects and Methods

Studies were carried out on 26 normal infants and children, mostly in-patients who had recovered from diseases not associated with renal or metabolic disturbances. No subjects with abnormal respiratory function, abnormal plasma electrolyte or blood urea levels, or abnormal urines were included. Where necessary urea and endogenous creatinine clearances were estimated, and found to be normal for their age.

Since little is known about younger infants after the neonatal period, it was thought desirable to divide the results now obtained into two groups, one including those children aged 1 year or less, and the other including children over 1 year old. The younger age-group consists of 12 infants, 6 girls and 6 boys, whose ages range from 2 to $11 \frac{1}{2}$ months, 3 of whom were only tested while on normal diets, 8 while on normal diets and also after $\mathrm{NH}_{4} \mathrm{Cl}$ had been added, and one only during $\mathrm{NH}_{4} \mathrm{Cl}$ administration. In each case, the infants were fed on a reconstituted dried cows' milk, with suitable semi-solid foods, except for one aged 2 months who was on the milk mixture only. The older group consists of 14 children, 5 girls and 9 boys, aged from 1 year 1 month to 16 years: 6 were tested both on normal diets and after $\mathrm{NH}_{4} \mathrm{Cl}$ had been added, and 8 only while $\mathrm{NH}_{4} \mathrm{Cl}$ was being given.

Collection of Urine. Urine was collected for a period of four to nine hours (average about six hours) during the day, each collection being accurately timed. Older children were asked to empty their bladder directly into chemically clean bottles or pots. The urine was collected from male infants by using Paul's tubing strapped around the penis, and from females by the use of a metabolic bed. The specimens were refrigerated and at the end of the test they were pooled and analysed immediately for $p \mathrm{H}$, titratable acidity (TA), titratable acidity less bicarbonate ( $\mathrm{TA}-\mathrm{HCO}_{3}{ }^{-}$) and ammonia. In most cases the $\mathrm{pH}$ of the individual specimens of each collection was also determined. Fluid intake was increased whenever possible in order to augment the urine flow, and thus minimize the error from incomplete emptying of the bladder. Incomplete collections due to leakage around the tube, or specimens contaminated with faeces, were discarded.

A blood sample for plasma $\mathrm{CO}_{2}$ content, and in some cases for blood $p \mathrm{H}$, was taken about the middle of the period during which urine was collected and two or three hours after a meal. 
TABLE 1

INFANTS AGED 2-11! MONTHS: INDIVIDUAL RESULTS, MEANS. AND RANGE

\begin{tabular}{|c|c|c|c|c|c|c|c|c|c|c|c|c|c|}
\hline \multirow{3}{*}{ No. } & \multirow{3}{*}{$\operatorname{Sex}$} & \multirow{3}{*}{$\underset{\text { (mth.) }}{\text { Age }}$} & \multirow{3}{*}{ Diet } & \multicolumn{2}{|c|}{ Blood } & \multicolumn{7}{|c|}{ Urine* } & \multirow{3}{*}{$\begin{array}{c}\mathbf{H}+ \\
\text { Clear- } \\
\text { ance } \\
\text { Index }\end{array}$} \\
\hline & & & & \multirow{2}{*}{$\begin{array}{c}\text { Plasma } \\
\mathrm{CO}_{2} \\
(\mathrm{mEq} / \mathrm{l} .)\end{array}$} & \multirow{2}{*}{$\begin{array}{c}\text { Whole } \\
\text { Blood } \\
p \mathrm{H}\end{array}$} & \multicolumn{2}{|c|}{$p \mathrm{H}$} & \multicolumn{4}{|c|}{$\mu \mathrm{Eq} / \mathrm{min} . / 1 \cdot 73$ sq. $\mathrm{m}$. } & \multirow{2}{*}{$\begin{array}{c}\mathrm{NH}_{4}^{+} \\
\text {in }^{+} \\
\mathrm{NH}_{4}^{+} \\
+\mathrm{TA}^{+}\end{array}$} & \\
\hline & & & & & & Range & $\begin{array}{c}\text { Pooled } \\
\text { Speci- } \\
\text { mens }\end{array}$ & $\mathrm{NH}_{4}+$ & TA & $\underset{\mathrm{HCO}_{3}^{-}}{\mathrm{TA}-}$ & $\begin{array}{c}\text { Total } \\
\mathrm{H}+\end{array}$ & & \\
\hline 1 & $\mathbf{M}$ & 2 & $\begin{array}{l}\text { Normal } \\
\text { Normal }+\mathrm{NH}_{4} \mathrm{Cl}\end{array}$ & $\begin{array}{l}19 \cdot 0 \\
18 \cdot 3\end{array}$ & $\begin{array}{l}7 \cdot 36 \\
7 \cdot 35\end{array}$ & $\begin{array}{l}5 \cdot 7-6 \cdot 3 \\
5 \cdot 0-5 \cdot 2\end{array}$ & $\begin{array}{l}5 \cdot 8 \\
5 \cdot 0\end{array}$ & $\begin{array}{l}18 \cdot 7 \\
26 \cdot 3\end{array}$ & $\begin{array}{l}35 \cdot 3 \\
40 \cdot 8\end{array}$ & - & $\begin{array}{l}54 \cdot 0 \\
67 \cdot 1\end{array}$ & $\begin{array}{l}34 \cdot 6 \\
39 \cdot 2\end{array}$ & $\begin{array}{l}1 \cdot 02 \\
1 \cdot 23\end{array}$ \\
\hline 2 & $\mathbf{F}$ & $3 \frac{1}{2}$ & Normal & $21 \cdot 5$ & & & $5 \cdot 1$ & $11 \cdot 7$ & $18 \cdot 7$ & - & $30 \cdot 4$ & $38 \cdot 5$ & 0.65 \\
\hline 3 & $\mathbf{M}$ & $\begin{array}{l}3 \frac{1}{2} \\
4\end{array}$ & $\begin{array}{l}\text { Normal } \\
\text { Normal }+\mathrm{NH}_{4} \mathrm{Cl}\end{array}$ & $\begin{array}{l}21 \cdot 0 \\
18 \cdot 5\end{array}$ & & $\begin{array}{l}5 \cdot 4-6 \cdot 6 \\
5 \cdot 1-6 \cdot 4\end{array}$ & $\begin{array}{l}5 \cdot 9 \\
5 \cdot 8\end{array}$ & $\begin{array}{l}28 \cdot 0 \\
47 \cdot 0\end{array}$ & $\begin{array}{l}23 \cdot 5 \\
42 \cdot 0\end{array}$ & - & $\begin{array}{l}51 \cdot 5 \\
89 \cdot 0\end{array}$ & $\begin{array}{l}45 \cdot 4 \\
53 \cdot 0\end{array}$ & $\begin{array}{l}1 \cdot 08 \\
1 \cdot 65\end{array}$ \\
\hline 4 & $\mathbf{F}$ & 4 & $\begin{array}{l}\text { Normal } \\
\text { Normal }+\mathrm{NH}_{4} \mathrm{Cl}\end{array}$ & $\begin{array}{l}20 \cdot 7 \\
15 \cdot 5\end{array}$ & $7 \cdot 36$ & $\begin{array}{l}6 \cdot 4-7 \cdot 3 \\
5 \cdot 3-6 \cdot 4\end{array}$ & $\begin{array}{l}6 \cdot 7 \\
5 \cdot 8\end{array}$ & $\begin{array}{r}7 \cdot 3 \\
62 \cdot 0\end{array}$ & $\begin{array}{r}3 \cdot 6 \\
20 \cdot 6\end{array}$ & $1 \cdot 1$ & $\begin{array}{r}8 \cdot 4 \\
82 \cdot 6\end{array}$ & $\begin{array}{l}67 \cdot 0 \\
75 \cdot 0\end{array}$ & $\begin{array}{l}0 \cdot 16 \\
1 \cdot 28\end{array}$ \\
\hline 5 & $\mathbf{M}$ & $\begin{array}{l}4 \\
7\end{array}$ & $\begin{array}{l}\text { Normal } \\
\text { Normal }+\mathrm{NH}_{4} \mathrm{Cl}\end{array}$ & $\begin{array}{l}19 \cdot 5 \\
20 \cdot 0\end{array}$ & $7 \cdot 45$ & $\begin{array}{l}5 \cdot 6-6 \cdot 4 \\
4 \cdot 7-5 \cdot 3\end{array}$ & $\begin{array}{l}5 \cdot 9 \\
4 \cdot 9\end{array}$ & $\begin{array}{r}34 \cdot 5 \\
100 \cdot 0\end{array}$ & $\begin{array}{l}33 \cdot 7 \\
72 \cdot 0\end{array}$ & - & $\begin{array}{r}68 \cdot 2 \\
172 \cdot 0\end{array}$ & $\begin{array}{l}50 \cdot 5 \\
58 \cdot 1\end{array}$ & $\begin{array}{l}1 \cdot 33 \\
3 \cdot 44\end{array}$ \\
\hline 6 & $\mathbf{F}$ & $4 \frac{1}{4}$ & Normal & $19 \cdot 0$ & & $5 \cdot 2-5 \cdot 5$ & $5 \cdot 3$ & $17 \cdot 9$ & $22 \cdot 1$ & - & $40 \cdot 0$ & $44 \cdot 8$ & $0 \cdot 76$ \\
\hline 7 & $\mathbf{M}$ & 6 & $\begin{array}{l}\text { Normal } \\
\text { Normal }+\mathrm{NH}_{4} \mathrm{Cl}\end{array}$ & $\begin{array}{l}20 \cdot 5 \\
17 \cdot 4\end{array}$ & $\begin{array}{l}7 \cdot 39 \\
7 \cdot 40\end{array}$ & $\begin{array}{l}6 \cdot 5-7 \cdot 2 \\
4 \cdot 9-5 \cdot 0\end{array}$ & $\begin{array}{l}6 \cdot 8 \\
4 \cdot 9\end{array}$ & $\begin{array}{l}10 \cdot 9 \\
31 \cdot 3\end{array}$ & $\begin{array}{l}14 \cdot 1 \\
45 \cdot 0\end{array}$ & $2 \cdot 3$ & $\begin{array}{l}13 \cdot 2 \\
76 \cdot 3\end{array}$ & $\begin{array}{l}43 \cdot 6 \\
41 \cdot 0\end{array}$ & $\begin{array}{l}0 \cdot 27 \\
1 \cdot 33\end{array}$ \\
\hline 8 & $\mathbf{M}$ & 8 & Normal & $20 \cdot 0$ & $7 \cdot 41$ & $5 \cdot 7-6 \cdot 6$ & $6 \cdot 0$ & $19 \cdot 7$ & $23 \cdot 4$ & $一$ & $43 \cdot 1$ & $45 \cdot 7$ & $0 \cdot 86$ \\
\hline 9 & $\mathbf{F}$ & 8 & $\begin{array}{l}\text { Normal } \\
\text { Normal }+\mathrm{NH}_{4} \mathrm{Cl}\end{array}$ & $\begin{array}{l}19 \cdot 0 \\
11 \cdot 0\end{array}$ & $\begin{array}{l}7 \cdot 44 \\
7 \cdot 46\end{array}$ & $\begin{array}{l}5 \cdot 5-6 \cdot 8 \\
4 \cdot 8-5 \cdot 0\end{array}$ & $\begin{array}{l}6 \cdot 1 \\
4 \cdot 9\end{array}$ & $\begin{array}{l}14 \cdot 3 \\
70 \cdot 0\end{array}$ & $\begin{array}{l}29 \cdot 5 \\
42 \cdot 8\end{array}$ & - & $\begin{array}{r}43 \cdot 8 \\
112 \cdot 8\end{array}$ & $\begin{array}{l}32 \cdot 7 \\
62 \cdot 0\end{array}$ & $\begin{array}{l}0 \cdot 83 \\
1 \cdot 24\end{array}$ \\
\hline 10 & $\mathbf{F}$ & $8 \frac{2}{3}$ & $\begin{array}{l}\text { Normal } \\
\text { Normal }+\mathrm{NH}_{4} \mathrm{Cl}\end{array}$ & $\begin{array}{l}19 \cdot 3 \\
11 \cdot 0\end{array}$ & $\begin{array}{l}7 \cdot 39 \\
7 \cdot 30\end{array}$ & $\begin{array}{l}5 \cdot 4-5 \cdot 9 \\
4 \cdot 6-5 \cdot 0\end{array}$ & $\begin{array}{l}5 \cdot 6 \\
4 \cdot 8\end{array}$ & $\begin{array}{l}31 \cdot 5 \\
59 \cdot 4\end{array}$ & $\begin{array}{l}41 \cdot 7 \\
49 \cdot 6\end{array}$ & - & $\begin{array}{r}73 \cdot 2 \\
109 \cdot 0\end{array}$ & $\begin{array}{l}43 \cdot 0 \\
54 \cdot 4\end{array}$ & $\begin{array}{l}1 \cdot 41 \\
1 \cdot 20\end{array}$ \\
\hline 11 & $\mathbf{F}$ & $\begin{array}{l}9 \\
9 \frac{1}{2}\end{array}$ & $\begin{array}{l}\text { Normal } \\
\text { Normal }+\mathrm{NH}_{4} \mathrm{Cl}\end{array}$ & $\begin{array}{l}19 \cdot 5 \\
18 \cdot 0\end{array}$ & & $5 \cdot 0-5 \cdot 2$ & $\begin{array}{l}5 \cdot 3 \\
5 \cdot 1\end{array}$ & $\begin{array}{l}30 \cdot 3 \\
44 \cdot 0\end{array}$ & $\begin{array}{l}35 \cdot 2 \\
25 \cdot 5\end{array}$ & - & $\begin{array}{l}65 \cdot 5 \\
69 \cdot 5\end{array}$ & $\begin{array}{l}46 \cdot 3 \\
63 \cdot 5\end{array}$ & $\begin{array}{l}1 \cdot 28 \\
1 \cdot 25\end{array}$ \\
\hline 12 & $\mathbf{M}$ & $11 \frac{1}{2}$ & $\mathrm{Normal}+\mathrm{NH}_{4} \mathrm{Cl}$ & $20 \cdot 0$ & & $5 \cdot 2-5 \cdot 3$ & $5 \cdot 2$ & $50 \cdot 0$ & $44 \cdot 5$ & - & $94 \cdot 5$ & $53 \cdot 0$ & $1 \cdot 89$ \\
\hline $\begin{array}{l}\text { Mean } \\
\text { Range } \\
\text { Mean } \\
\text { Range }\end{array}$ & & $\begin{array}{l}\cdots \\
\cdots \\
\cdots\end{array}$ & $\begin{array}{l}\text { Normal } \\
\text { Normal } \\
\text { Normal }+\mathrm{NH}_{4} \mathrm{Cl} \\
\text { Normal }+\mathrm{NH}_{4} \mathrm{Cl}\end{array}$ & $\begin{array}{c}19 \cdot 9 \\
19 \cdot 0- \\
21 \cdot 5 \\
16 \cdot 6 \\
11 \cdot 0- \\
20 \cdot 0\end{array}$ & & & $\begin{array}{l}5 \cdot 1- \\
6 \cdot 8 \\
4 \cdot 8- \\
5 \cdot 8\end{array}$ & $\begin{array}{l}20 \cdot 4 \\
7 \cdot 3- \\
34 \cdot 5 \\
54 \cdot 4 \\
26 \cdot 3- \\
100 \cdot 0\end{array}$ & $\begin{array}{c}25 \cdot 5 \\
3 \cdot 6- \\
41 \cdot 7 \\
42 \cdot 5 \\
20 \cdot 6- \\
72 \cdot 0\end{array}$ & - & $\begin{array}{l}44 \cdot 7 \\
8 \cdot 4- \\
73 \cdot 2 \\
97 \cdot 0 \\
67 \cdot 1- \\
172 \cdot 0\end{array}$ & $\begin{array}{c}46 \cdot 3 \\
32 \cdot 7- \\
67 \cdot 0 \\
55 \cdot 8 \\
39 \cdot 2- \\
75 \cdot 0\end{array}$ & $\begin{array}{c}0 \cdot 88 \\
0 \cdot 16- \\
1 \cdot 41 \\
1 \cdot 61 \\
1 \cdot 20- \\
3 \cdot 44\end{array}$ \\
\hline
\end{tabular}

$\mathrm{TA}=$ Titratable Acidity

* In all the Tables urinary excretions are expressed in $\mu \mathrm{Eq} / \mathrm{min} . / 1.73 \mathrm{sq} . \mathrm{m}$. and not in $\mathrm{mEq}$, as in text, because of the small amounts involved.

Hydrogen Ion Loading. The renal response to an added load of hydrogen ions was tested by giving $\mathrm{NH}_{4} \mathrm{Cl}$, usually for three days or in some cases for four or five days. Since the results in those few who had $\mathrm{NH}_{4} \mathrm{Cl}$ for the longer period did not differ significantly from the mean values of the majority who had been given it for three days, all the results have been analysed together. The dose of $\mathrm{NH}_{4} \mathrm{Cl}$ was from 6.0 to $9 \cdot 0 \mathrm{~g}$. $(115-166 \mathrm{mEq}) /$ day $/ 1.73 \mathrm{sq} . \mathrm{m}$., the actual dose being $1 \cdot 0$ to $7.5 \mathrm{~g}$. day according to surface area. Each subject had the same amount daily, divided in three to four doses given with or after meals, to the younger children as a mixture in syrup, and to the older in uncoated capsules. No side-effects were observed apart from slight vomiting in three subjects on the second day of administration, but this was never severe enough to necessitate withdrawal of the $\mathrm{NH}_{4} \mathrm{Cl}$. A few of the older children were given the salt at home, but all came into hospital for the last day of the test. The urine was collected during the last day of $\mathrm{NH}_{4} \mathrm{Cl}$ administration as described above, blood being taken two to three hours after a meal, when the subject had already taken the first of the three or four daily doses of $\mathrm{NH}_{4} \mathrm{Cl}$.
The surface area was calculated from the height and weight using the Du Bois and Du Bois (1916) nomograms.

\section{Laboratory Methods.}

Plasma $\mathrm{CO}_{2}$ Content. Approximately $1 \mathrm{ml}$. capillary blood, obtained by finger- or heel-prick, was collected dropwise in heparinized $2 \times \frac{3}{8}$ in. test-tubes without paraffin oil. The plasma was then separated by centrifuging and kept for analysis within one to four hours. The $\mathrm{CO}_{2}$ content was measured manometrically (Van Slyke and Neill, 1924).

BLOOD $p \mathrm{H}$. This was determined on capillary blood collected in heparinized glass capillary tubes, both ends of which were sealed immediately after collection and examined within an hour after sampling. The $p \mathrm{H}$ was determined at $37^{\circ} \mathrm{C}$. using a microcapillary glass electrode (Metrohm) and a $p \mathrm{H}$ meter with a Vibron electrometer (Electronic Instruments Ltd.).

URINE $p \mathrm{H}$. This was determined at room temperature by external indicators using B.D.H. capillators.

AMmonia. This was estimated by aeration and titration (Hawk, Oser, and Summerson, 1954). 
The titratable acidity of the urine was determined by titration to $p \mathrm{H} 7 \cdot 4$ with $\mathrm{N} / 20 \mathrm{NaOH}$. When the $p \mathrm{H}$ was greater than $6 \cdot 2$, titratable acidity minus bicarbonate (TA $-\mathrm{HCO}_{3}{ }^{-}$) was measured (Albright and Reifenstein, 1948).

\section{Calculation.}

The Hydrogen Ion Clearance Index $=\mathrm{H}^{+}$excretion $(\mathrm{mEq} / \mathrm{min} . / 1.73$ sq. $\mathrm{m}$. $) \times$ plasma $\mathrm{CO}_{2}$ content $(\mathrm{mEq} / \mathrm{l}$.$) .$ Where $\mathrm{H}^{+}$excretion $=\mathrm{TA}+\mathrm{NH}_{4}{ }^{+}-\mathrm{HCO}_{3}{ }^{-}$each being expressed in $\mathrm{mEq} / \mathrm{min} . / 1 \cdot 73 \mathrm{sq} . \mathrm{m}$.

\section{Results}

The individual findings for the younger age-group are shown in Table 1 and for the older in Table 2.

A comparison of the results in the two groups shows that both on normal diet and after $\mathrm{NH}_{4} \mathrm{Cl}$ has been added, the plasma $\mathrm{CO}_{2}$ was about $2 \mathrm{mEq} / \mathrm{l}$. lower in the infants under 1 year. Urine $p \mathrm{H}$ was approximately the same in the two groups, as was the output of $\mathrm{NH}_{4}{ }^{+}$, though after $\mathrm{NH}_{4} \mathrm{Cl}$, this was a little higher in the older group. However, the urine of infants showed a higher titratable acidity than the children, both before and during $\mathrm{NH}_{4} \mathrm{Cl}$ administration and therefore a smaller proportion of $\mathrm{H}^{+}$was excreted as $\mathrm{NH}_{4}{ }^{+}$.

It is interesting to note that under normal dietary conditions the total $\mathrm{H}^{+}$excreted by the older agegroup was about one-third less than the amount excreted by the infants. This may be explained by the fact that the diet of children contains less protein per $\mathrm{kg}$. body weight than that of young infants who are being fed mainly on cows' milk, and the relatively large amount of phosphate in cows' milk also contributes to the excess of TA in the urine. After the acid load, the total $\mathrm{H}^{+}$in the urine of both groups was the same but the proportion of TA remained higher in infants, the children compensating by an increase in ammonia production.

There is no marked difference between the two agegroups in the mean values of the $\mathrm{H}^{+}$clearance index after $\mathrm{NH}_{4} \mathrm{Cl}$ administration, though by exclusion of one exceptionally high index in the infant group a

TABLE 2

CHILDREN AGED 1 YEAR AND 1 MONTH TO 16 YEARS: INDIVIDUAL RESULTS, MEANS, AND RANGE

\begin{tabular}{|c|c|c|c|c|c|c|c|c|c|c|c|c|c|}
\hline \multirow{3}{*}{ No. } & \multirow{3}{*}{ Sex } & \multirow{3}{*}{$\begin{array}{l}\text { Age } \\
\text { (yr.) }\end{array}$} & \multirow{3}{*}{ Diet } & \multicolumn{2}{|c|}{ Blood } & \multicolumn{7}{|c|}{ Urine } & \multirow{3}{*}{$\begin{array}{c}\mathrm{H}+ \\
\text { Clear- } \\
\text { ance } \\
\text { Index }\end{array}$} \\
\hline & & & & \multirow{2}{*}{$\begin{array}{c}\text { Plasma } \\
\mathrm{CO}_{2} \\
(\mathrm{mEq} / \mathrm{l} .)\end{array}$} & \multirow{2}{*}{$\begin{array}{c}\text { Whole } \\
\text { Blood } \\
p \mathrm{H}\end{array}$} & \multicolumn{2}{|c|}{$p \mathrm{H}$} & \multicolumn{4}{|c|}{$\mu \mathrm{Eq} / \mathrm{min} . / 1 \cdot 73$ sq. m. } & \multirow{2}{*}{$\begin{array}{c}\%_{\%} \\
\mathrm{NH}_{4}+ \\
\text { in } \\
\mathrm{NH}_{4}+ \\
+\mathrm{TA}\end{array}$} & \\
\hline & & & & & & Range & $\begin{array}{l}\text { Pooled } \\
\text { Speci- } \\
\text { mens }\end{array}$ & $\mathrm{NH}_{4}+$ & TA & $\mathrm{TAO}_{3-}$ & $\begin{array}{c}\text { Total } \\
\mathrm{H}+\end{array}$ & & \\
\hline 1 & $\mathrm{~F}$ & $11 / 12$ & $\begin{array}{l}\text { Normal } \\
\text { Normal }+\mathrm{NH}_{4} \mathrm{Cl}\end{array}$ & $\begin{array}{l}19 \cdot 2 \\
14 \cdot 0\end{array}$ & $\begin{array}{l}7 \cdot 42 \\
7 \cdot 37\end{array}$ & $4 \cdot 8-5 \cdot 8$ & $\begin{array}{l}5 \cdot 7 \\
5 \cdot 3\end{array}$ & $\begin{array}{r}23 \cdot 4 \\
111 \cdot 0\end{array}$ & $\begin{array}{l}24 \cdot 2 \\
53 \cdot 8\end{array}$ & 二. & $\begin{array}{r}47 \cdot 6 \\
164 \cdot 8\end{array}$ & $\begin{array}{l}49 \cdot 3 \\
67 \cdot 5\end{array}$ & $\begin{array}{l}0 \cdot 92 \\
2 \cdot 30\end{array}$ \\
\hline 2 & $\mathrm{~F}$ & $14 / 12$ & Normal $+\mathrm{NH}_{4} \mathrm{Cl}$ & $16 \cdot 0$ & $7 \cdot 42$ & $5 \cdot 4-5 \cdot 7$ & $5 \cdot 6$ & $59 \cdot 4$ & $26 \cdot 5$ & - & $85 \cdot 9$ & $69 \cdot 2$ & $1 \cdot 38$ \\
\hline 3 & F & $110 / 12$ & $\stackrel{\text { Normal }}{\text { Normal }}+\mathrm{NH}_{4} \mathrm{Cl}$ & $\begin{array}{l}22 \cdot 0 \\
14 \cdot 9\end{array}$ & $\begin{array}{l}7 \cdot 36 \\
7 \cdot 31\end{array}$ & $\begin{array}{l}6 \cdot 0-6 \cdot 3 \\
4 \cdot 9-5 \cdot 2\end{array}$ & $\begin{array}{l}6 \cdot 2 \\
5 \cdot 0\end{array}$ & $\begin{array}{l}26 \cdot 8 \\
87 \cdot 0\end{array}$ & $\begin{array}{l}12 \cdot 0 \\
44 \cdot 2\end{array}$ & 二 & $\begin{array}{r}38 \cdot 8 \\
131 \cdot 2\end{array}$ & $\begin{array}{l}69 \cdot 0 \\
66 \cdot 3\end{array}$ & $\begin{array}{l}0.85 \\
1.96\end{array}$ \\
\hline 4 & $\mathbf{M}$ & $26 / 12$ & Normal $+\mathrm{NH}_{4} \mathrm{Cl}$ & $21 \cdot 0$ & & $5 \cdot 1-5 \cdot 2$ & $5 \cdot 1$ & $50 \cdot 0$ & $25 \cdot 5$ & - & $75 \cdot 5$ & $66 \cdot 2$ & $1 \cdot 58$ \\
\hline 5 & $\mathbf{M}$ & $34 / 12$ & Normal $+\mathrm{NH}_{4} \mathrm{Cl}$ & $16 \cdot 8$ & & $5 \cdot 2-5 \cdot 2$ & $5 \cdot 2$ & $53 \cdot 0$ & $30 \cdot 0$ & - & $83 \cdot 0$ & $64 \cdot 0$ & $1 \cdot 40$ \\
\hline 6 & $\mathbf{M}$ & 4 & Normal $+\mathrm{NH}_{4} \mathrm{Cl}$ & $18 \cdot 5$ & & & $4 \cdot 8$ & $65 \cdot 0$ & $33 \cdot 3$ & - & $98 \cdot 3$ & $66 \cdot 0$ & $1 \cdot 82$ \\
\hline 7 & $\mathbf{M}$ & 4 & Normal $+\mathrm{NH}_{4} \mathrm{Cl}$ & $17 \cdot 0$ & & $4 \cdot 9-5 \cdot 1$ & $5 \cdot 0$ & $71 \cdot 8$ & $26 \cdot 0$ & - & $97 \cdot 8$ & $73 \cdot 4$ & 1.66 \\
\hline 8 & $\mathrm{~F}$ & $48 / 12$ & Normal $+\mathrm{NH}_{4} \mathrm{Cl}$ & $18 \cdot 5$ & & $5 \cdot 0-5 \cdot 7$ & $5 \cdot 3$ & $70 \cdot 0$ & $30 \cdot 0$ & - & $100 \cdot 0$ & $70 \cdot 0$ & $1 \cdot 85$ \\
\hline 9 & $\mathbf{M}$ & 5 & Normal $+\mathrm{NH}_{4} \mathrm{Cl}$ & $20 \cdot 0$ & & $5 \cdot 1-5 \cdot 2$ & $5 \cdot 1$ & $45 \cdot 7$ & $27 \cdot 0$ & - & $72 \cdot 7$ & $63 \cdot 0$ & $1 \cdot 45$ \\
\hline 10 & $\mathbf{F}$ & $53 / 12$ & $\begin{array}{l}\text { Normal } \\
\text { Normal }+\mathrm{NH}_{4} \mathrm{Cl}\end{array}$ & $\begin{array}{l}25 \cdot 8 \\
21 \cdot 3\end{array}$ & & & $\begin{array}{l}7 \cdot 2 \\
4 \cdot 7\end{array}$ & $\begin{array}{l}18 \cdot 2 \\
48 \cdot 2\end{array}$ & $\begin{array}{r}2 \cdot 0 \\
13 \cdot 9\end{array}$ & $-7 \cdot 9$ & $\begin{array}{l}10 \cdot 3 \\
62 \cdot 1\end{array}$ & $\begin{array}{l}90 \cdot 0 \\
77 \cdot 6\end{array}$ & $\begin{array}{l}0 \cdot 26 \\
1 \cdot 32\end{array}$ \\
\hline 11 & $\mathbf{M}$ & $59 / 12$ & $\begin{array}{l}\text { Normal } \\
\text { Normal }+\mathrm{NH}_{4} \mathrm{Cl}\end{array}$ & $\begin{array}{l}24 \cdot 8 \\
21 \cdot 4\end{array}$ & $\begin{array}{l}7 \cdot 40 \\
7 \cdot 37\end{array}$ & $5 \cdot 2-5 \cdot 4$ & $\begin{array}{l}5 \cdot 3 \\
4 \cdot 8\end{array}$ & $\begin{array}{l}11 \cdot 2 \\
65 \cdot 0\end{array}$ & $\begin{array}{l}18 \cdot 9 \\
42 \cdot 7\end{array}$ & - & $\begin{array}{r}30 \cdot 1 \\
107 \cdot 7\end{array}$ & $\begin{array}{l}37 \cdot 2 \\
60 \cdot 4\end{array}$ & $\begin{array}{l}0 \cdot 74 \\
2 \cdot 3\end{array}$ \\
\hline 12 & $\mathbf{M}$ & $83 / 12$ & Normal $+\mathrm{NH}_{4} \mathrm{Cl}$ & $17 \cdot 5$ & & $4 \cdot 6-5 \cdot 6$ & $4 \cdot 8$ & $47 \cdot 6$ & $24 \cdot 0$ & - & $71 \cdot 6$ & $66 \cdot 5$ & $1 \cdot 25$ \\
\hline 13 & $\mathbf{M}$ & 14 & $\stackrel{\text { Normal }}{\text { Normal }}+\mathrm{NH}_{4} \mathrm{Cl}$ & $\begin{array}{l}20 \cdot 0 \\
18 \cdot 0\end{array}$ & $\begin{array}{l}7 \cdot 51 \\
7 \cdot 45\end{array}$ & $\begin{array}{l}5 \cdot 4-6 \cdot 4 \\
4 \cdot 7-5 \cdot 1\end{array}$ & $\begin{array}{l}6 \cdot 0 \\
4 \cdot 9\end{array}$ & $\begin{array}{l}28 \cdot 6 \\
62 \cdot 0\end{array}$ & $\begin{array}{l}10 \cdot 5 \\
31 \cdot 0\end{array}$ & 二 & $\begin{array}{l}39 \cdot 1 \\
93 \cdot 0\end{array}$ & $\begin{array}{l}73 \cdot 2 \\
66 \cdot 7\end{array}$ & $\begin{array}{l}0.78 \\
1.68\end{array}$ \\
\hline 14 & $\mathbf{M}$ & 16 & $\begin{array}{l}\text { Normal } \\
\text { Normal }+\mathrm{NH}_{4} \mathrm{Cl}\end{array}$ & $\begin{array}{l}22 \cdot 8 \\
19 \cdot 8\end{array}$ & $\begin{array}{l}7 \cdot 47 \\
7 \cdot 40\end{array}$ & $\begin{array}{l}6 \cdot 6-6 \cdot 8 \\
5 \cdot 2-5 \cdot 7\end{array}$ & $\begin{array}{l}6 \cdot 7 \\
5 \cdot 5\end{array}$ & $\begin{array}{l}17 \cdot 3 \\
73 \cdot 0\end{array}$ & $\begin{array}{r}3 \cdot 5 \\
15 \cdot 2\end{array}$ & $-\underline{-8 \cdot 3}$ & $\begin{array}{r}9 \cdot 0 \\
88 \cdot 2\end{array}$ & $\begin{array}{l}83 \cdot 1 \\
83 \cdot 0\end{array}$ & $\begin{array}{l}0.20 \\
1.74\end{array}$ \\
\hline \multicolumn{2}{|c|}{$\begin{array}{l}\text { Mean ... } \\
\text { Range.. }\end{array}$} & & $\begin{array}{l}\text { Normal } \\
\text { Normal }\end{array}$ & $\begin{array}{l}22 \cdot 4 \\
19 \cdot 2-\end{array}$ & & & $5 \cdot 3-$ & $\begin{array}{r}20 \cdot 9 \\
11 \cdot 2-\end{array}$ & $\begin{array}{l}11.9 \\
2 \cdot 0-\end{array}$ & - & $\begin{array}{l}29 \cdot 2 \\
9 \cdot 0\end{array}$ & $\begin{array}{r}64 \cdot 0 \\
37 \cdot 0\end{array}$ & $\begin{array}{r}0.63 \\
0.20\end{array}$ \\
\hline \multicolumn{2}{|c|}{$\begin{array}{l}\text { Mean ... } \\
\text { Range.. }\end{array}$} & & $\begin{array}{l}\text { Normal }+\mathrm{NH}_{4} \mathrm{Cl} \\
\text { Normal }+\mathrm{NH}_{4} \mathrm{Cl}\end{array}$ & $\begin{array}{c}25 \cdot 8 \\
18 \cdot 2 \\
14 \cdot 0- \\
21 \cdot 4\end{array}$ & & & $\begin{array}{c}7 \cdot 2 \\
4 \cdot 7- \\
5 \cdot 6\end{array}$ & $\begin{array}{r}28 \cdot 6 \\
64 \cdot 5 \\
45 \cdot 7- \\
111 \cdot 0\end{array}$ & $\begin{array}{r}24 \cdot 2 \\
30 \cdot 2 \\
13 \cdot 9- \\
53 \cdot 8\end{array}$ & 二 & $\begin{array}{l}47 \cdot 6 \\
95 \cdot 1 \\
62 \cdot 1- \\
164 \cdot 8\end{array}$ & $\begin{array}{c}90 \cdot 0 \\
68 \cdot 4 \\
61 \cdot 0- \\
83 \cdot 0\end{array}$ & $\begin{array}{l}0.92 \\
1.69 \\
1.25- \\
2 \cdot 30\end{array}$ \\
\hline
\end{tabular}

TA = Titratable acidity 


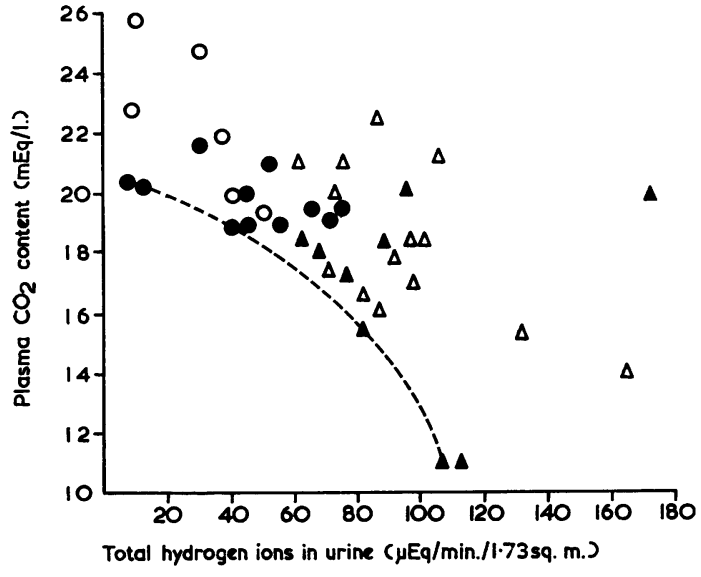

FIG. 1.-The relation of plasma $\mathrm{CO}_{2}$ content to the rate of total hydrogen ion excretion in urine (infants and children). The interrupted line shows the limit of normal values.

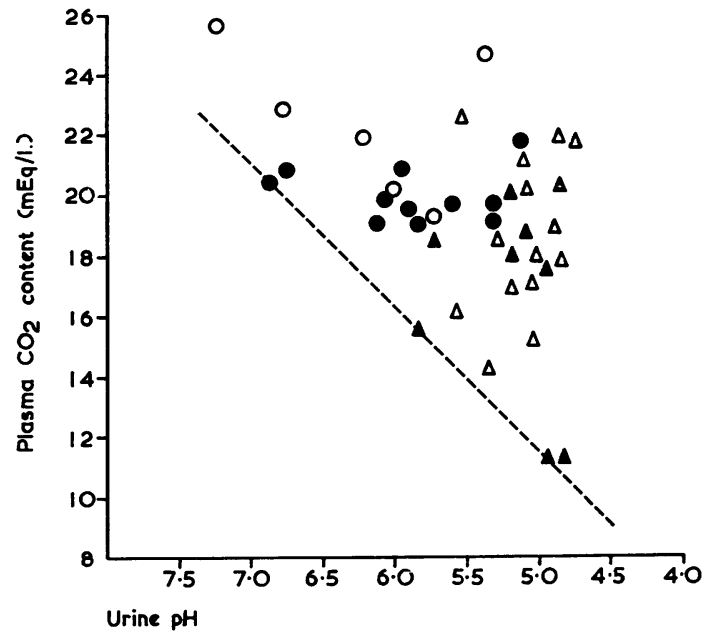

FIG. 2.-The relation of plasma $\mathrm{CO}_{2}$ content to urine $p \mathrm{H}$ (infants and children). The interrupted line shows the limit of normal values. Symbols as in Fig. 1.

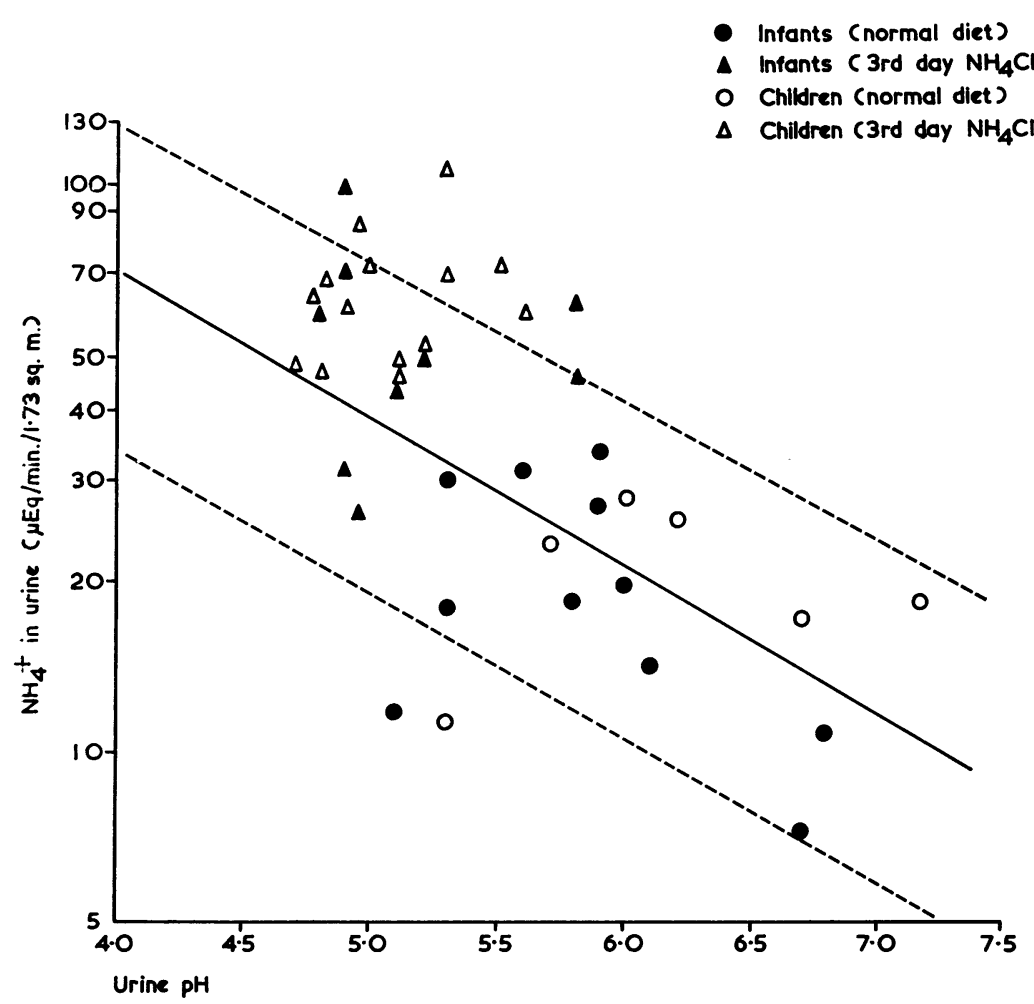

FIG. 3.-The relation of ammonium ion excretion to the $p H$ of urine (infants and children). The bold line is the mean and the interrupted lines represent the $95 \%$ confidence limits for adults (Wrong, 1961). Symbols as in Fig. 1. 
lower mean index would have been obtained. This is due to lower plasma $\mathrm{CO}_{2}$ values rather than lower total $\mathrm{H}^{+}$excreted in the urine.

The index in subjects receiving a free diet varied widely. It can be very low or even negative if the diet is alkaline, when the subject is excreting more $\mathrm{HCO}_{3}{ }^{-}$than $\mathrm{NH}_{4}{ }^{+}$and TA together. In these cases the renal ability to excrete $\mathrm{H}^{+}$can be assessed by plotting the plasma $\mathrm{CO}_{2}$ against total $\mathrm{H}^{+}$excreted in the urine. In Fig. 1 the results for both infants and children on normal diets and after $\mathrm{NH}_{4} \mathrm{Cl}$ administration have been plotted in this way. The interrupted line joining the lower points of the graph indicates the lower limit of the values for the infants: the lower normal limit for children is slightly higher than the one for infants. Infants or children whose values fall below this line may be considered abnormal as far as renal ability to excrete $\mathrm{H}^{+}$is concerned. Fig. 2 similarly shows the relation between plasma $\mathrm{CO}_{2}$ and urine $p \mathrm{H}$. Fig. 3 shows the $\mathrm{NH}_{4}{ }^{+}$output in relation to urinary $p \mathrm{H}$ and includes also the normal limits and the mean for adults given by Wrong (1961). Under normal dietary conditions the values for all our control subjects except two-one infant and one child-fell within the normal limits for adults, while after stressing with $\mathrm{NH}_{4} \mathrm{Cl}$, several of them exceeded the upper limits of normal for adults.

The percentage of $\mathrm{H}^{+}$excreted as $\mathrm{NH}_{4}{ }^{+}$is a useful index of ammonia production. Our lowest figure for this percentage is 32.7 in infants and 37 in children. McCance, Matheson, Gresham, and Elkinton (1960) consider that figures below 30\% indicate impaired ammonia production. Two of the present subjects whose ratio of ammonia to urine $p \mathrm{H}$ was below the normal limits for adults (as shown in Fig. 3) also had a comparatively low percentage of $\mathrm{H}^{+}$excreted as $\mathrm{NH}_{4}{ }^{+}$, but this increased in one of them, who was tested after $\mathrm{NH}_{4} \mathrm{Cl}$, from $37 \cdot 2$ to $60 \cdot 4 \%$.

\section{Discussion}

Though the tests were arranged so that the results could be compared with those of Elkinton et al. (1960) for adults, there were difficulties in doing this, and the findings are not exactly comparable. Difficulties in obtaining accurate 24-hour specimens were avoided by using short periods of urine collections that did not require admission to hospital overnight. A further advantage in this procedure is that the urine could be analysed without delay, thus minimizing the risks of changes due to bacterial activity. Rates of daily $\mathrm{H}^{+}$excretion calculated from a short period of the day are probably not representative of the average rates for the whole 24 hours, measured by Elkinton et al. (1960), since urine passed at night tends to be more acid than that during the day. Furthermore, both the meals and the divided doses of $\mathrm{NH}_{4} \mathrm{Cl}$ administered during the collection period may have resulted in rapid and brief changes in the blood chemistry and the urine acidity, but blood for analysis was always taken at the same time after meals to offset this possibility.

The normal capillary plasma $\mathrm{CO}_{2}$ content in this study ranged from $19-25 \cdot 8 \mathrm{mEq} / \mathrm{l}$., which is lower than the range given by Singer and Hastings (1948) for arterial plasma in adults. The dropwise collection of blood, and the omission of paraffin oil in the collecting tube may have contributed to these lower values. In this laboratory, blood is no longer collected under oil because of the practical difficulties, one of which is always ensuring adequate mixing of drops of capillary blood under oil. Gambino (1961) has drawn attention to the fact that mineral oil may result in big losses of $\mathrm{CO}_{2}$ due to its high solubility in oil. The routine method in this laboratory is to equilibrate the specimen with alveolar air only if it is not analysed within three to four hours after its collection, but this hardly ever needed to be done in the present investigation.

For comparison, the findings from our infant group have been tabulated together with those from infants aged 2-10 months recorded in the literature (Table 3). Unfortunately as the technique and methods of investigation among the different authors have differed, the results may not be entirely comparable. Thus, Gordon, McNamara, and Benjamin (1948) and McCance et al. (1960) analysed 24-hour urine specimens, while Fomon, Harris, and Jensen (1959) used 12-hour night specimens of urine. The latter authors analysed venous blood and this gave higher values of $\mathrm{CO}_{2}$ content in their series than in ours. The $\mathrm{H}^{+}$output of our infants is higher than in the breast-fed infants reported by Fomon $e t$ al. and in the artificially fed infants by McCance et al., but it is much lower than that of the infants fed on cows' milk investigated by Gordon et al. (1948) and Fomon et al. (1959). Low $\mathrm{H}^{+}$excretion is to be expected in breast-fed infants compared with those who are artificially fed, but it is difficult to explain the large differences observed among infants fed artificially (Table 3), unless their diets were quite different, especially with regard to protein consumption.

The output of $\mathrm{H}^{+}$by our normal infants $(66 \mathrm{mEq} /$ $24 \mathrm{hr} . / 1 \cdot 73$ sq. m.) under normal dietary conditions is approximately the same as by two infants, aged 8 months and 1 year, studied by Widdowson and McCance (1958) (if their output is calculated per 1.73 sq. $\mathrm{m}$. surface area, assuming each was of 
TABLE 3

EXCRETION OF HYDROGEN IONS IN NORMAL INFANTS ON NORMAL DIET AND AFTER AMMONIUM CHLORIDE: PRESENT SERIES AND SOME PREVIOUSLY PUBLISHED FIGURES

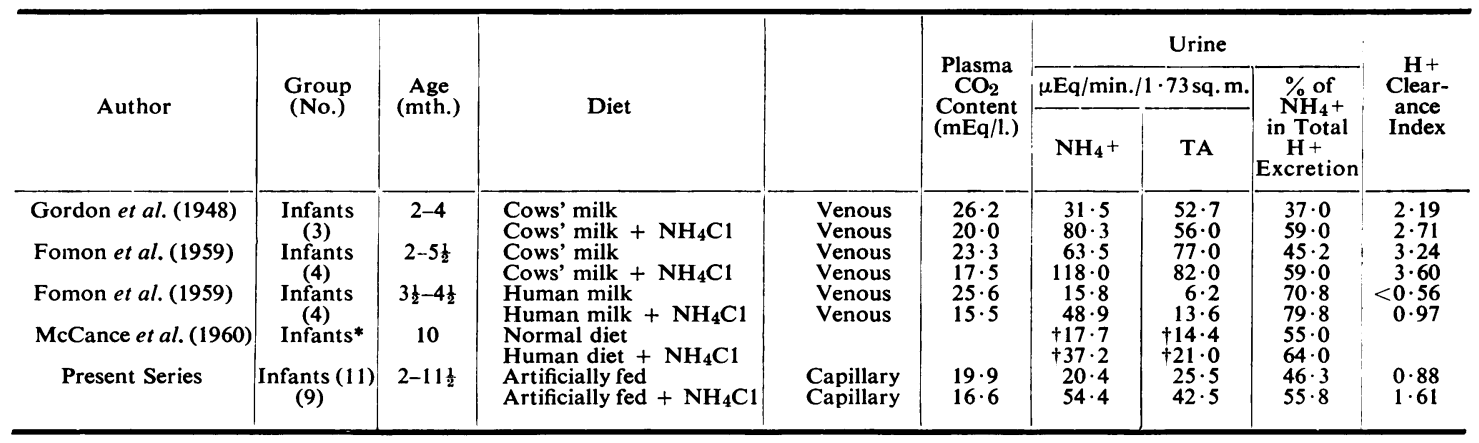

* The number of patients included is not stated. The series includes some infants studied by the authors, and others taken from published reports + Calculated from authors' data.

TABLE 4

EFFECT OF $\mathrm{NH}_{4} \mathrm{CL}$ ADMINISTRATION ON RENAL EXCRETION OF HYDROGEN IONS: NORMAL INFANTS AND CHILDREN (PRESENT SERIES) AND PREVIOUSLY PUBLISHED VALUES IN ADULTS

\begin{tabular}{|c|c|c|c|c|c|c|c|}
\hline \multirow{2}{*}{ Author } & \multirow{2}{*}{ Group (No.) } & \multirow{2}{*}{ Age } & & \multirow{2}{*}{$\begin{array}{c}\text { Mean } \\
\text { Plasma } \\
\mathrm{CO}_{2} \\
(\mathrm{mEq} / \mathrm{l} .)\end{array}$} & \multirow{2}{*}{$\begin{array}{c}\text { Mean } \\
\text { Total } \mathbf{H}+ \\
\text { Excretion } \\
\text { in Urine } \\
(\mu \text { Eq/min./ } \\
1.73 \text { sq. } \mathrm{m} .)\end{array}$} & \multicolumn{2}{|c|}{$\mathrm{H}^{+}$Clearance Index } \\
\hline & & & & & & Mean & Range \\
\hline Present series & Infants (9) & $2-11 \frac{1}{2} \mathrm{mth}$. & Capillary & $16 \cdot 6$ & $97 \cdot 0$ & $1 \cdot 61$ & $1 \cdot 20-3 \cdot 44$ \\
\hline Present series & Children (14) & $13 \mathrm{mth} .-16 \mathrm{yr}$. & Capillary & $18 \cdot 2$ & $95 \cdot 1$ & $1 \cdot 69$ & $1 \cdot 25-2 \cdot 30$ \\
\hline Elkinton et al. (1960) & Adults (17) & & Venous (serum) & $20 \cdot 7$ & $100 \cdot 0$ & $2 \cdot 07$ & $1 \cdot 40-3 \cdot 40$ \\
\hline
\end{tabular}

normal body weight and height for age) and by adults reported by Elkinton et al. (1960). All are much higher than those for infants on the first, second, and eighth day of life (Widdowson and McCance, 1958).

The response to $\mathrm{NH}_{4} \mathrm{Cl}$ induced acidosis by both infants and children in our series (Table 4) is practically the same as that in adults (Elkinton et al., 1960), though the clearance indices of adults are slightly higher owing to higher serum $\mathrm{CO}_{2}$ levels. The present observations indicate that the kidneys of the children examined were able to cope as efficiently with the stress of $\mathrm{H}^{+}$added to normal feeding as those of adults. Hatemi and McCance (1961), investigating the response of newborn infants to a single dose of $\mathrm{NH}_{4} \mathrm{Cl}$, found that $\mathrm{H}^{+}$excretion was much less than in adults after a similar stress, the mean clearance indices in newborns being only $21 \%$ of their mean adult values. Our results now show that in the infant the specific renal function of acidifying the urine under stress has, presumably by a process of maturation, achieved adult level by about 3 months of age. Though the number of the younger infants examined in this series is not large enough to suggest the earliest age at which this maturation occurs in any individual, the results can be used as a basis for the assessment of acidosis of renal origin with increasing confidence over the age of 3 months.

\section{Summary}

The renal ability to excrete hydrogen ions was assessed in 12 normal infants aged 2-11 $\frac{1}{2}$ months and 14 children aged 1 year 1 month to 16 years on ordinary diets, and in most cases on the third day of continuous ammonium chloride administration. Titratable acidity and ammonium ion excretion in the urine and the carbon dioxide content in the plasma were determined within the same period, and from these values the hydrogen ion clearance index has been calculated for each child. The mean and range for the index in both age-groups, as well as the total hydrogen ions excreted/1.73 sq. m. surface area, were found to have reached adult levels.

It is considered that the values for these normal children are suitable to use as a standard that can be applied in assessing whether acidosis is, or is not, primarily of renal origin in children from the age of about 3 months. 


\section{REFERENCES}

Albright, F., and Reifenstein, E. C., Jr. (1948). The Parathyroid Glands and Metabolic Bone Disease. Williams and Wilkins, Baltimore.

Buchanan, E. U., and Komrower, G. M. (1958). The prognosis of idiopathic renal acidosis in infancy with observations on urine acidification and ammonia production in children. Arch. Dis. Childh., 33, 532.

Du Bois, D., and Du Bois, E. F. (1916). Clinical calorimetry. X. A formula to estimate the approximate surtace area if height and weight be known. Arch. intern. Med., 17, 863.

Elkinton, J. R., Huth, E. J., Webster, G. D., Jr., and McCance, R. A. (1960). The renal excretion of hydrogen ion in renal tubular acidosis. I. Quantitative assessment of the response to ammonium chloride as an acid load. Amer. J. Med., 29, 554.

Fomon, S. J., Harris, D. M., and Jensen, R. L. (1959). Acidification of the urine by infants fed human milk and whole cows' milk. Pediatrics, 23, 113.

Gambino, S. R. (1961). Mineral oil and carbon dioxide. Amer. J. clin. Path., 35, 268.

Gordon, H. H., McNamara, H., and Benjamin, H. R. (1948). The response of young infants to ingestion of ammonium chloride. Pediatrics, 2, 290.

Hatemi, N., and McCance, R. A. (1961). Renal aspects of acid-base control in the newly born. III. Response to acidifying drugs. Acta paediat. (Uppsala), 50, 603.

Hawk, P. B., Oser B. L., and Summerson, W. H. (1954). Practical Physiological Chemistry, 13th ed., p. 889. Churchill, London.

Huth, E. J., Webster, G. D., Jr., and Elkinton, J. R. (1960). The renal excretion of hydrogen ion in renal tubular acidosis. III. An attempt to detect latent cases in a family; comments on nosology, genetics and etiology of the primary disease. Amer.J. Med., 29, 586.

McCance, R. A., Matheson, W. J., Gresham, G. A., and Elkinton, J. R. (1960). The cerebro-ocular-renal dystrophies: a new variant. Arch. Dis. Childh., 35, 240.

Singer, R. B., and Hastings, A. B. (1948). An improved clinical method for the estimation of disturbances of the acid-base balance of human blood. Medicine (Baltimore), 27, 223.

Van Slyke, D. D., and Neill, J. M. (1924). The determination of gases in blood and other solutions by vacuum extraction and manometric measurement. J. biol. Chem., 61, 523.

Widdowson, E. M., and McCance, R. A. (1958). The development of acid-base control. In Ciba Foundation. Colloquia on Ageing, Vol. 4, p. 209. Churchill, London.

Wrong, O. (1961). Personal communication quoted by Berlyne, G. M. in Distal tubular function in chronic hydronephrosis. Quart. J. Med., 30, 339.

disease. Quart. J. Med., 28, 259. 